\title{
Unilateral Fusion of Two Primary Mandibular Teeth: Report of a Portuguese Archeological Case
}

\author{
Ana Maria Silva* and Ana Leonor Silva \\ Centro de Investigação em Antropologia, Department of Anthropology, University of Coimbra, 3000 - 056 \\ Coimbra - Portugal
}

ABSTRACT: This paper describes a unilateral fusion
of two mandibular teeth in an infant skeleton recovered
from the late Roman cemetery of Miroiço (Sintra,
Portugal). Morphological and radiographic data were
used for the analysis and interpretation of this dental

Double teeth, that is, two conjoined teeth, are considered a clinical manifestation of two developmental anomalies taking place during the bud stage of tooth formation: gemination and fusion. Gemination is the attempt of division of a single tooth germ whereas fusion, the joining together of two dental germs (Alpoz et al., 2003; Gurri and Balam, 2006; Tomizawa et al., 2002). There is a general agreement that it is sometimes difficult to separate these two events, due to the possibility of synchronous anomalies (Neves et al., 2002). Thus, some authors argue that these two developmental events should not be separated while others propose that some diagnostic criteria be used, such as counting the teeth in the affected arch (Gurri and Balam, 2006) and radiological analysis (Neves et al., 2002; Santos et al., 2003; Schuurs and van Loveren, 2002). Fusion, for instant, will diminish the number of teeth, whereas gemination will not (Gurri and Balam, 2006; Neves et al., 2002; Tomizawa et al., 2002).

According to the clinical literature, the most commonly involved double teeth are central and lateral incisors, followed by lateral incisors and canines (Gurri and Galam, 2006; Neves et al., 2002; Santos et al., 2003; Schuurs and van Loveren, 2000; Tomizawa et al., 2002). Double teeth are more common in the primary dentition, ranging from $0.4 \%$ to $0.9 \%$ in the mandible and are predominantly unilateral (Schuurs and van Loveren, 2002). The majority of reports conclude that there is no sex preference for this anomaly (Santos et al., 2003; Schuurs and van Loveren, 2000). A family tendency has been suggested (Santos et al. 2003). Rarely, fusion in three elements is reported (Erdem et al., 2001; Mochizuki et al., 1999).

This paper reports an archeological case of double teeth, probably due to a unilateral fusion of two lower deciduous teeth, a lateral incisor and a canine. anomaly. A brief review of the literature of present day primary dental fusion is presented. This report shows that primary dental fusion was present in Portuguese past populations, representing a contribution to the history of dental anomalies. Dental Anthropology 2007;20:16-18.

\section{MATERIALS AND METHODS}

During osteological analysis of the human remains (minimal number of 64 individuals) recovered from the late Roman cemetery of Miroiço (Sintra, Portugal) (Macedo, 2002; Silva, 2003), a case of double primary mandibular teeth was recognized in the infant skeleton labelled 30.2. Although not firmly dated, it appears that the necropolis may have been in use during the 2nd 4th centuries AD (Cardoso, 2001).

Age at death of this infant skeleton was estimated with the dental remains. The formation of each tooth crown was assessed using the standards of Smith (1991). Maturation of the recovered teeth is consistent with an age of death of 3 to 4 years old. There is consistency of this age at death assessed throughout the recovered dentition.

\section{CASE REPORT}

From the lower primary dentition of infant skeleton labelled 30.2 (Fig. 1A), only the two central incisors and the crowns of the left first molar were missing. In the position of teeth 72 and 73 (Fig. 1B), a double teeth was observed. Since no anomaly was observed in the right mandibular quadrant, this represents a unilateral event. From the maxilla, only the right arch was recovered with teeth 51 to 55 and the crowns of teeth 11, 12, 13, 14 and 15 , visible through a postmortem broken area of the bone. Teeth 65 and crown of teeth 26 were recovered as loose teeth.

*Correspondence to: Ana Maria Silva, Centro de Investigação em Antropologia, Department of Anthropology, University of Coimbra, 3000 - 056 Coimbra - Portugal

E-mail: amgsilva@antrop.uc.pt 

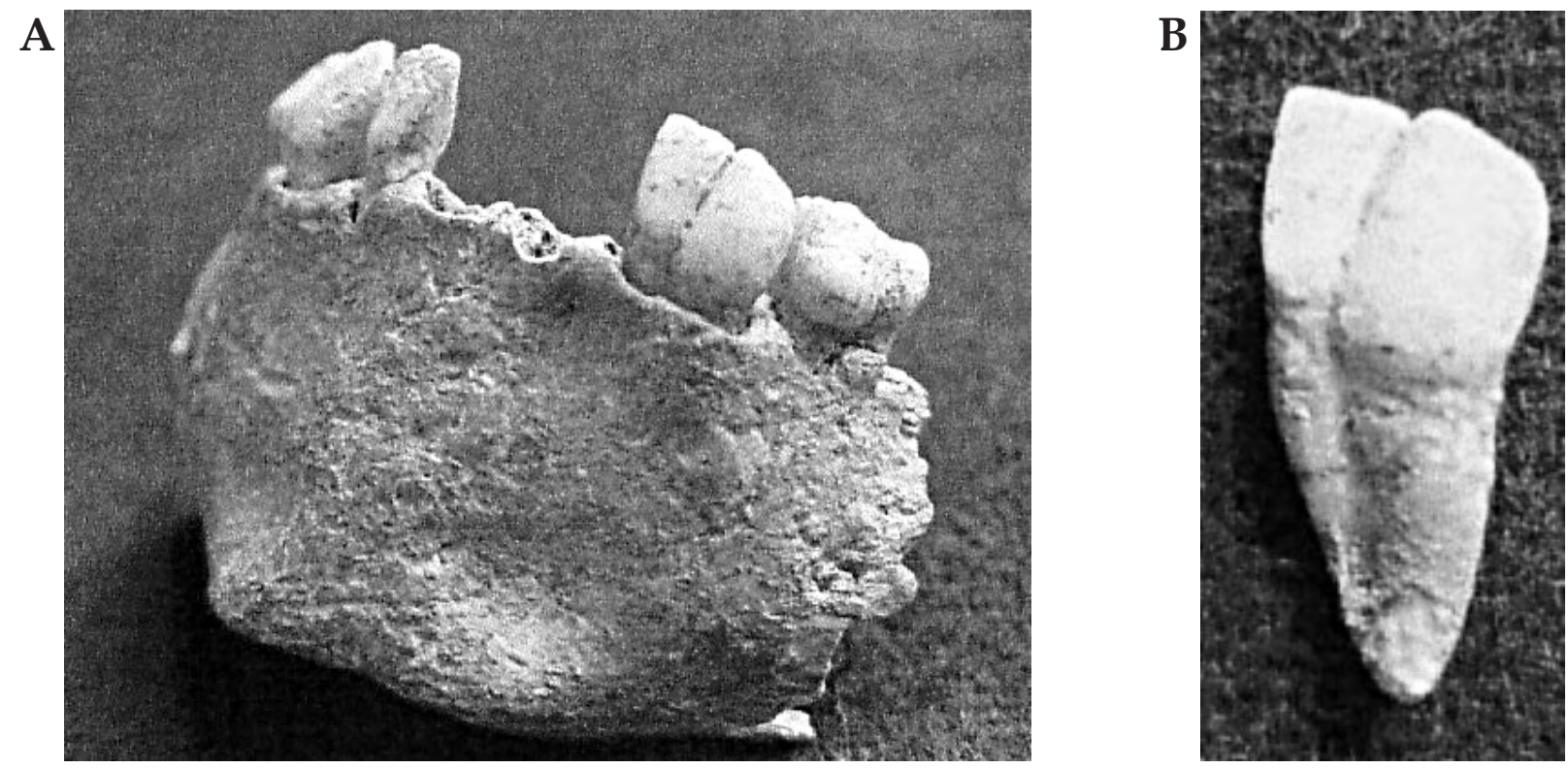

Fig. 1. Dental remains recovered from infant skeleton 30.2 from the late Roman cemetery of Miroiço (Portugal). $(A)$ view of the anterior portion of the mandible; $(B)$ detail of the double teeth from the mandibular left quadrant.

The double teeth displays a bifid crown with a well defined buccal groove that extends from the incisal edge to the apex of the root (Fig. 1B). In lingual view, the groove is readily visible between the incisal edge to initial cervical two-third of the crown, being very tenuous along the rest of the tooth.

Radiographic examination revealed that the double tooth has two separate pulp chambers and root canals (Figs. 2 and 3). No other bony or dental anomaly, such as supernumerary teeth, was detected in the skeletal remains from this infant.

\section{DISCUSSION}

This paper describes a case of double teeth detected in the primary dentition of a late Roman infant skeleton that seems to result from the fusion of teeth 72 and 73. This diagnosis is based on the tooth count and on radiological examination. Although clinical cases are described in the literature (Aguiló et al., 1999; Alpoz et al, 2003; Gurri and Balam, 2006; Neves et al., 2002; Schuurs and van Loveren, 2000; Tomizawa et al. 2002), this anomaly seems to be rare in past populations. To our knowledge, this is the first report of an archeological case, although another unpublished case was recovered from Peru, involving lower first and second deciduous incisors (oral communication from Prof. Simon Hillson).

The fusion is incomplete and took place late in odontogenesis resulting in a readily discernible fused crown and two roots. Radiographical examination (Figs. 2 and 3) revealed two separate pulp chambers and root canals. Although many clinical reports found association of fusion of primary teeth with succedaneous ones (e.g., Reddy and Munshi, 1999), no other abnormality was detected in the present case.

Clinical problems related to double teeth include caries along the grooves dividing each crown, esthetics, and malocclusion (Neves et al., 2002; Santos et al., 2003). In the present archeological case, only the former issue could be analyzed. No cariogenic lesion was detected in the double teeth or any other tooth recovered from the dentition of this late Roman child.

Regarding the etiology of this dental anomaly, Neves et al. (2002) proposed genetic inheritance or physical pressure leading to the union of teeth. In a recent review, Gurri and Balam (2006) concluded that fusion is probably associated with a mandibular extension of tooth reduction and that it is under different genetic control of gemination. Gemination, in contrast, could be link to a maxillary extension of tooth enlargement and increment in number. Unfortunately, no inferences are possible in the present archeological case because in the human remains unearthed from this Necropolis no other dental anomalies were detected.

In sum, in recent years interdisciplinary studies in areas such as paleopathology, odontology and radiology (Chimenos-Küstner et al., 2006; Jordana et al., 2004), as in the present study, are contributing to the documention and interpretation of past (Silva, 2002) and present dental anomalies (Aguiló et al., 1999; Alpoz et al., 2003; Gurri and Balam, 2006; Neves et al., 2002; Schuurs and van Loveren, 2000; Tomizawa et al., 2002). 


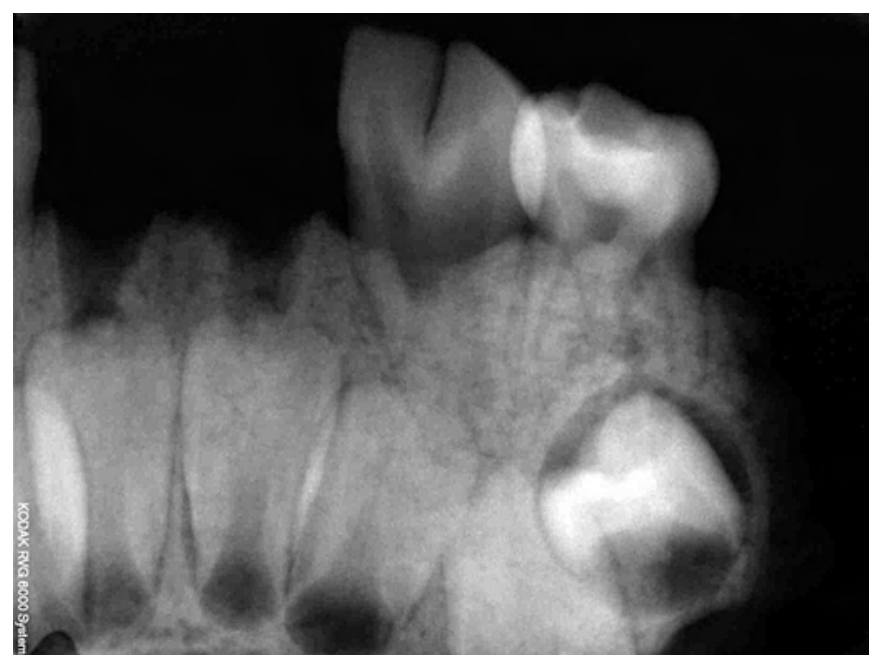

Fig. 2. Posterio-anterior radiograph of the mandible of infant skeleton 30.2 from Miroiço (Portugal). Note the double teeth in positions 72 and 73 .

\section{ACKNOWLEDGMENTS}

We would like to thank Maria Teresa Ferreira and Eugénia Cunha (Departamento de Antropologia da Universidade de Coimbra); Ana Corte Real (Faculdade de Medicina Dentária, University of Coimbra); Simon Hillson (Institute of Archaeology, University College London), Miguel Costa (Dentist), and Câmara Municipal de Sintra.

\section{LITERATURE CITED}

Aguiló L, Gamdia JL, Cibrian R, Catala M. 1999. Primary double teeth. A retrospective clinical study of their morphological characteristics and associated anomalies. Int J Pediatric Dent 9:175-183.

Alpoz AR, Munanoglu D, Oncag O. 2003. Mandibular bilateral fusion in primary dentition: case report. J Dent Child 70:74-76.

Cardoso G. 2001. A Necrópole de Miroiço (Manique - Cascais). Unpublished field report.

Chimenos-Küstner E, Agustí-Farjas B, Probable keratocyst in a mandible from the late Roman era. Dentomaxillofacial Radiol 35:60-64.

Erdem G, Uzamis M, Ölmez S, Sargon M. Primary incisor triplication defect. ASDC J Dent Child 68:322-325.

Gurri F, Balam G. 2006. Inheritance of bilateral fusion of the lower central and lateral incisors: a pedigree of a Maya family from Yucatan, Mexico. Dental Anthropology 19:29-34.

Jordana X, García C, Palacios M, Chimenos E, Malgosa A. 2004. Bifid mandibular condyle: archaeological case report of a rare anomaly. Dentomaxillofacial Radiol 33:278-281.

Macedo M. 2002. Villa Romana de Miroiço... uma leitura. Estudo Paleobiológico de uma amostra de esqueletos

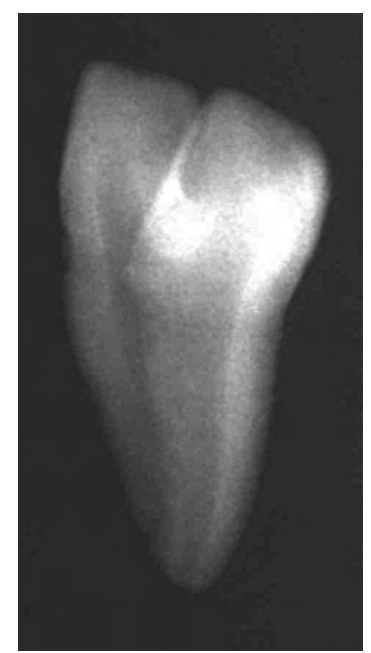

Fig. 3. Labiolingual radiograph of the double teeth from infant skeleton 30.2 from Miroiço (Portugal).

de Manique - Cascais. Tese de licenciatura. Coimbra, Departamento de Antropologia da F.C.T.U.C.. Unpublished report.

Mochizuki K, Yonezu T, Yakushiji M, Machida Y. 1999. The fusion of three primary incisors: Report of case. ASDC J Dent Child 66:421-425

Neves AA, Neves MLA, Farinhas JA. 2002. Bilateral connation of permanent mandibular incisors: a case report. Int J Paediatric Dent 12:61-65.

Reddy NN, Munshi AK. 1999. Fusion of primary incisors-a report of six cases. J Indian Soc Pedod Prev Dent 17:55-60.

Santos LM, Forte FDS, Rocha MJC. 2003. Pulp therapy in a maxillary fused primary central incisor - report of a case. Int J Paediatric Dent 13:274-278.

Schuurs AHB, van Loveren C. Anomalies. 2000. Double teeth: review of the literature. ASDC J Dent Child 67:313-325.

Silva AM. 2002. Antropologia funerária e Paleobiologia de populações Portuguesas do Neolítico final/Calcolítico. Tese de Doutoramento em Antropologia Biológica, Coimbra, Departamento de Antropologia da F.C.U.T.U. Unpublished Ph.D. thesis.

Silva, AL. 2003. Registo de um quotidiano....na Villa Romana de Miroiço. Análise paleobiológica de uma amostra de esqueletos exumados da Necrópole de Miroiço. Tese de licenciatura. Coimbra, Departamento de Antropologia da F.C.T.U.C. Unpublished report.

Smith BH. 1991. Standards of human tooth formation and dental age assessment. In: Kelley M, Larsen CS, editors. Advances in Dental Anthropology. New-York: Wiley-Liss, 1991, p 143-168.

Tomizawa M, Shimizu A, Hayashi S, Noda T. 2002. Bilateral maxillary fused primary incisors accompanied by succedaneous supernumerary teeth: report of a case. Int J Paediatric Dent 12:223-227. 